\title{
トピックス
}

\section{II. 治療}

\section{2. 合併症のある高血圧の治療}

\section{己）慢性腎臓病}

\section{大蔵 隆文 檜垣 實男}

要旨

高血圧患者の腎機能を評価するには，血清クレアチニンのみでは不十分であり，推定糸球体ろ過值によ る評価, さらに血清シスタチン值も参考にしながら, 正確な腎機能評価を行う必要がある. 慢性腎臓病は, 末期腎不全のリスクとなるばかりでなく，心血管病のリスクでもあり，これらのリスクの軽減のためには 厳格な血圧管理が最も重要である。降圧薬としては, ACE阻害薬もしくはアンジオテンシン受容体拮抗薬 が第一選択薬であるが, 併用が必要な場合は, 利尿薬もしくはCa拮抗薬の使用が勧められるが, 患者の病 態を十分把握して選択する必要がある.

〔日内会誌 $100 ： 385 ３ 93 ， 2011 〕$

Key words 慢性腎臓病, レニンーアンジオテンシン系阻害薬, シスタチンC, 心血管病

はじめに

血圧が高ければ高いほど腎機能は悪化し，腎 機能が悪化すればするほど血圧が上昇する.Multiple Risk Factor Intervention Trial(MRFIT)で は, 332,544 人の男性を対象として末期腎不全に 至る確率を検討した ${ }^{11}$ 。 そして平均 16 年間の観 察期間で 814 人が末期腎不全と診断された $(15.6$ 例 $/ 10$ 万人・年あたり). その中で高血圧が末期 腎不全にいたる強いリスクであり, 収縮期血圧 が>210 mmHgもしくは拡張期血圧が>120 $\mathrm{mmHg}$ の男性では, 収縮期血圧が $<120 \mathrm{mmHg}$
かつ拡張期血圧 $<80 \mathrm{mmHg}$ の男性と比較して, 22.1 倍末期腎不全になりやすいことが報告された (図 1). 血圧が正常であっても腎機能は加齢と共 に低下し, 通常, 糸球体ろ過值 (GFR) は年間 約 0.3〜 $1 \mathrm{ml}$ 低下する。このGFRが, 慢性腎臓病 (Chronic kidney disease : CKD)の患者では年間 4〜8 ml/分低下する.このGFRの低下速度は, 血 圧をより低くコントロールすればするほど，遅 くなることが明らかとなっている ${ }^{2)}$. 従って, 日 本高血圧治療ガイドライン 2009 （JSH2009）で は, CKDの患者では, 目標血圧值を $130 / 80 \mathrm{mmHg}$ 未満, さらに蛋白尿が $1 \mathrm{~g} /$ 日以上認められる場 合は $125 / 75 \mathrm{mmHg}$ 未満と撖格な降圧治療を推奨

愛媛大学病態情報内科学

Chronic renal disease.

Takafumi Okura and Jitsuo Higaki : Department of Integrated Medicine and Informatics, Ehime University Graduate School of Medicine, Japan. 


\section{トピックス}

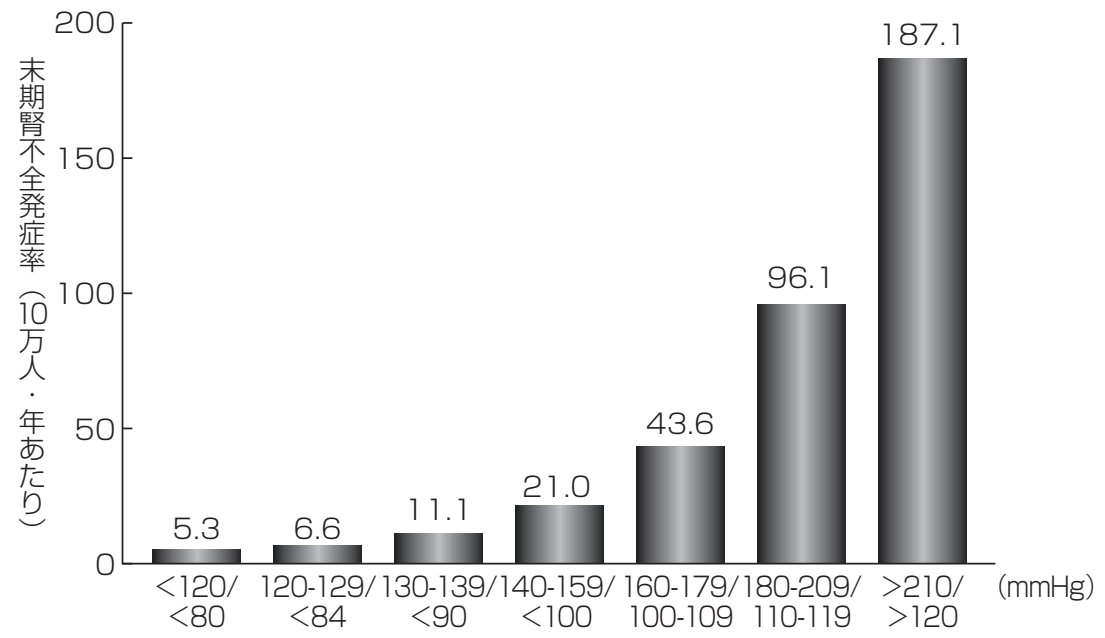

図 1. 高血圧は末期腎不全移行の重要な危険因子である

(文献 1 より引用改変)

している3).

\section{CKDと心血管病 (cardio-vascular dis- ease : CVD)}

腎機能低下やタンパク尿が末期腎不全のリス クであるだけでなく, CVDの強力なリスクであ ることが明らかとなっている．末期腎不全の増 加, CVDの発症抑制のためには, 腎機能低下ゃ タンパク尿の出現を早期に発見, 治療すること が必要であり,このためにCKDの概念が提唱さ れ, 現在広く普及しつつある. CKDの診断には, 糸球体ろ過量 (glomerular filtration rate : GFR) の計測が必要であり，すべての高血圧患者にお いて, 推定GFR (estimate GFR : eGFR) で腎機 能を評価し, 検尿でタンパク尿の有無を評価す べきである。

CKDとCVDの関連に関しては, 日本で行われ た大規模臨床試験でも示されている. CASE-J 研究では, 心血管病に影響した因子として年齢, 脳疾患関連因子（脳出血, 脳梗塞, 一過性脳虚 血発作), 心疾患関連因子 (左室肥大, 狭心症, 心筋梗塞), 糖尿病, さらに最も影響した因子は
腎疾患関連因子（尿タンパク陽性, クレアチニ ンミ1.3 mg/dl)であった ${ }^{4}$ (図 2)．また最近報告 されたJATOS研究のサブ解析でも, eGFR $\leqq 60$ $\mathrm{ml} / \mathrm{min} / 1.73 \mathrm{~m} 2$ および登録時および終了時の夕 ンパク尿が強力な心血管病発症の危険因子であっ たことを報告し，日本人においても，心腎連関 が認められることを証明した。

\section{2. 腎機能評価法とシスタチンC}

腎機能評価法として, eGFRの評価が重要であ るが, 血中シスタチンCも腎機能の指標として利 用されている. シスタチンC (cystatin C) は, 13 キロダルトンの内因性cysteine proteinase inhibitorの一つであり, 全身の有核細胞から一定の 割合で産生され，腎糸球体ですべてろ過された 後, 近位尿細管で再吸収され，そこで分解され る。したがってその血中濃度は, GFRに依存し ている.さらに, 血清クレアチニンと比較して, 腎障害の早期から変化が認められること, 年齢, 性別, 炎症等の影響を受けにくいことから, ク レアチニンよりも, 有効な早期腎障害診断マー カーと考えられている. さらに最近の報告でシ 


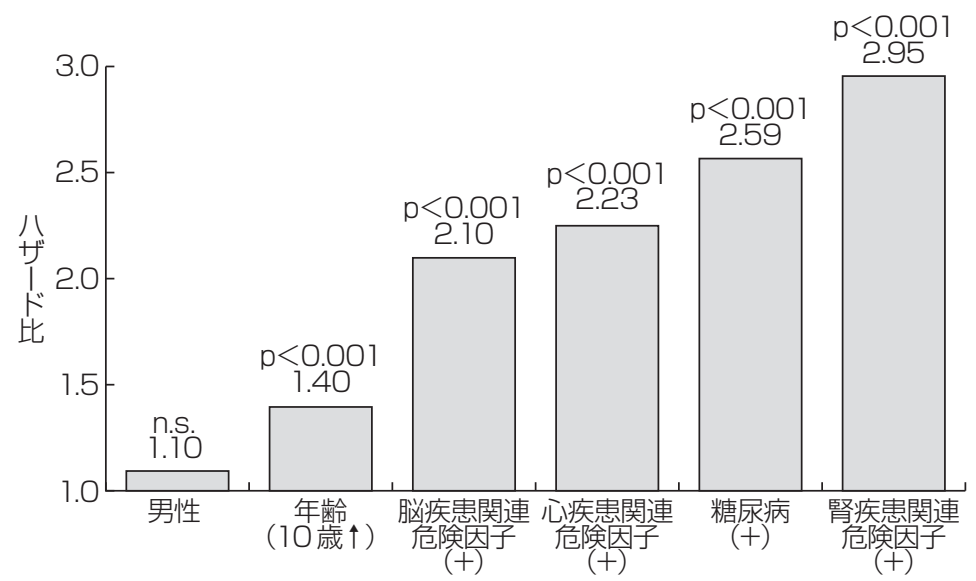

図 2. 日本人における心血管病発症の危険因子

(文献 4 より引用改変)

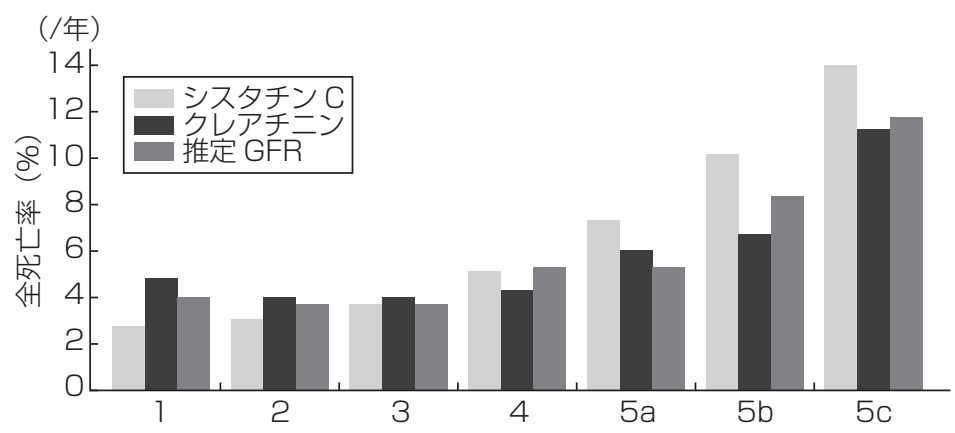

図 3. シスタチンCは高齢者において死亡の予測因子である

(文献 5 より引用改変)

スタチンCは, 単に腎機能の指標としてだけでは なく, 心不全や死亡の予測因子として注目され つつある。

Shlipakらは, 65 歳以上の高齢者 4,637人を対 象として, シスタチンCおよびクレアチニンの測 定を行った後, 平均 7.4 年間の観察を行い, 死亡 および心血管病の発症とシスタチンCおよびクレ アチニンとの関連を検討した5). 図 3 に示すよう に, シスタチンC, クレアチニン值掞よびクレア チニンから推定したeGFRによって症例を 5 分位 し(5 分位目に関してはさらに 3 分位を行った), それぞれの死亡率を検討したところ，シスタチ ンCで分類した群では, シスタチンCが高ければ
高いほど，死亡率が上昇していた。これに対し て,クレアチニンおよびeGFRで分類した群では, 直線的な関係は認められず, Jカーブの関連が認 められた。このことから, シスタチンCは, 高齢 者において死亡の独立した予測因子であること が証明された。 そしてShlipakらはさらに,これ らの対象からeGFRが正常な高齢者を抽出し, 同 様な検討を行い, シスタチンCのみが, 死亡およ び心血管病発症の独立した規定因子であること を明らかにした $\left(\right.$ 図 4) ${ }^{6)}$. これらのことからシス タチンCは腎機能障害を越えた心血管病や死亡の 予測因子であることが推測される. 


\section{トピックス}
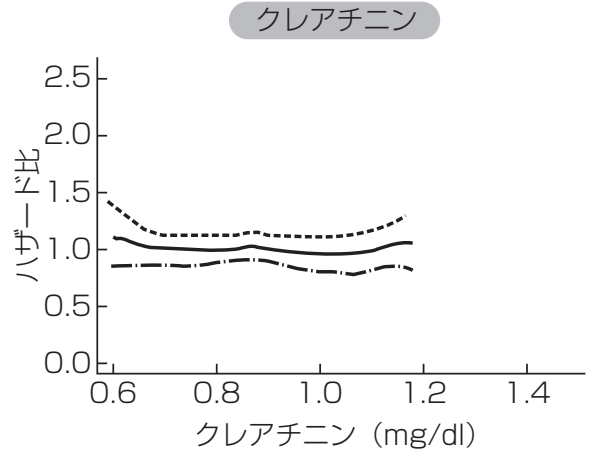

推定 GFR

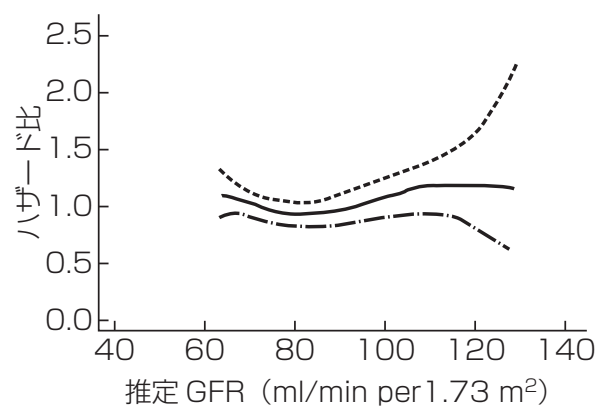

シスタチンC

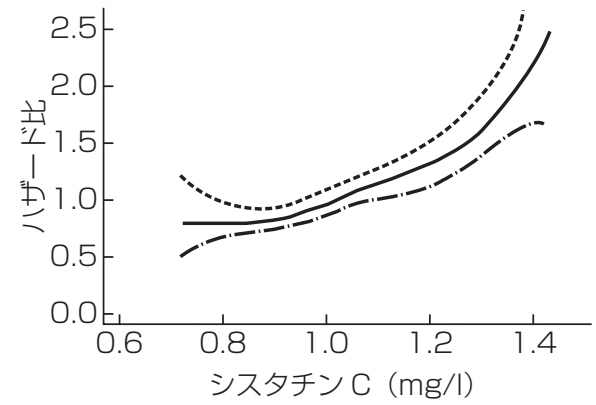

図 4. シスタチンCは糸球体ろ過值が正常でも高齢者の死亡予測因子である

(文献 6 より引用改変)

\section{3. シスタチンCと炎症関連因子}

それでは,なぜこのようにシスタチンCは心血 管病や死亡の予測因子となるのであろうか. こ のことを明らかにするために，私どもは， 88 人の高血圧患者を対象として, 心血管病や死亡 の予測因子である, 高感度CRP (hs-CRP), interleukin-6（IL-6）およびTumor necrosis factor (TNF)- $\alpha$ とシスタチンCとの関連を検討した ${ }^{7}$. その結果, シスタチンCは, eGFR, 収縮期血圧, 脈圧と関連したのに対して, 血清クレアチニン は, eGFRしか有意の相関関係は認められなかっ た(表).さらに, シスタチンCは, IL-6 および TNF- $\alpha$ とも有意の相関関係を認めたが，これら の関係はクレアチニンでは認められなかった.

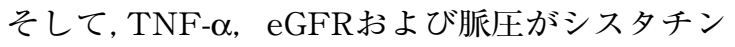

Cの独立した規定因子であったこのように，シ スタチンCは, 炎症関連因子と関連することによ り, 血清クレアチニンと比較して, より強い心 血管病の予測因子となりうることが推定された.

\section{4. レニンーアンジオテンシン (RA) 系抑 制薬と慢性腎臓病}

腎機能障害の進行には, 高血圧に加えて, ア ンジオテンシンII（AII）が重要な役割を演じて いる. AIIは糸球体輸出細動脈を収縮させ糸球体 内圧を上昇させると共に, 腎内のIL-6, TGF- $\beta$, MCP-1, MMP-2 やMMP-9 等を増加し, 腎臓内 の炎症, 線維化を促進させる. 従って, AIIの作 用を抑制するAngiotensin converting enzyme (ACE) 阻害薬, アンジオテンシンII受容体拮抗 薬（ARB）の腎保護効果が期待され, 事実多く 
表. シスタチンCと関連因子

\begin{tabular}{l|c|r|r|r}
\hline & シスタチンC & \multicolumn{1}{|c|}{$\mathrm{p}$} & \multicolumn{1}{c}{ クレアチニン } & \multicolumn{1}{c}{$\mathrm{p}$} \\
\hline 年齢 & 0.213 & 0.067 & -0.047 & 0.690 \\
BMl & 0.051 & 0.666 & -0.096 & 0.417 \\
収縮期血圧 & 0.246 & 0.034 & -0.032 & 0.788 \\
拡張期血圧 & 0.081 & 0.493 & 0.058 & 0.626 \\
脈圧 & 0.295 & 0.010 & 0.137 & 0.244 \\
HbA 1c & 0.008 & 0.948 & -0.206 & 0.077 \\
LDLコレステロール & -0.093 & 0.433 & -0.153 & 0.194 \\
HDLコレステロール & -0.010 & 0.932 & 0.001 & 0.923 \\
eGFR & -0.503 & $<0.001$ & -0.755 & $<0.001$ \\
& & & & \\
In TNF- $\alpha$ & 0.405 & $<0.001$ & 0.172 & 0.142 \\
In IL-6 & 0.247 & 0.033 & -0.099 & 0.403 \\
In CRP & 0.188 & 0.108 & -0.195 & 0.096 \\
\hline
\end{tabular}

BMI: body mass index, HbAlc: hemoglobin A 1c, LDL-Cho: Low density lipoprotein-cholesterol, HDL-Cho: High density lipoprotein-cholesterol, eGFR: estimated glomerular filtration rate, TNF- $\alpha$ : tumor necrosis factor- $\alpha$, IL-6: Interleukin-6, CRP: C-reactive protein, In: log natural

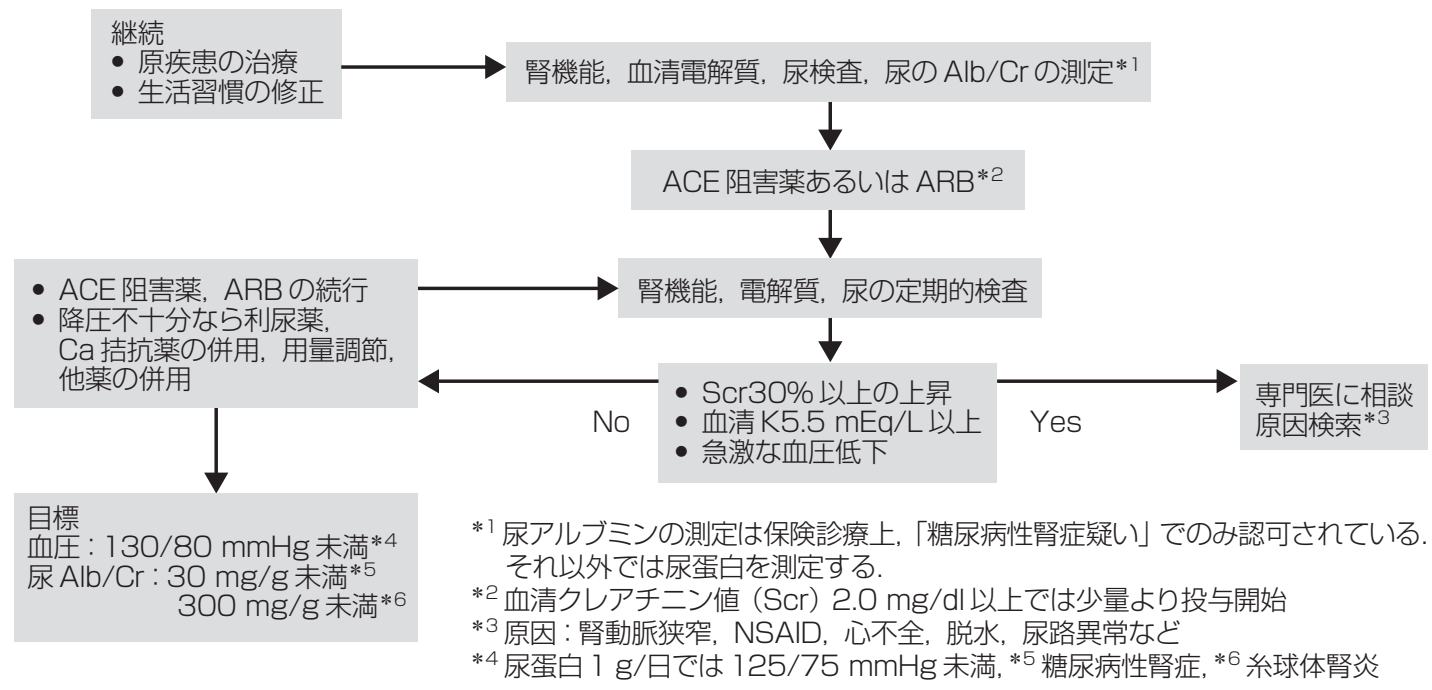

図 5. 慢性腎臓病を合併した高血圧患者の治療指針

(文献 3 より引用)

の大規模臨床試験でもその効果が証明され, CKD を有する高血圧患者の第一選択薬となっている (図 5).それでは, RA阻害薬であるARBとACE 阻害薬に腎保護効果に差があるのだろうか. Kunz らは, メ夕解析で, ARBとACE阻害薬のタンパ ク尿低下作用の差異を検討した ${ }^{8)}$. 図 6 に示すよ
うに，両者で同等のタンパク尿の低下作用が認 められた。さらに, 彼らは, ARBもしくはACE 阻害薬の単剂と両者の併用でタンパク尿低下作 用に差があるかを検討し，両者の併用が単剂よ りもより有効であることも報告している(図 7). しかし, Ontarget試験では, ARBおよびACE 


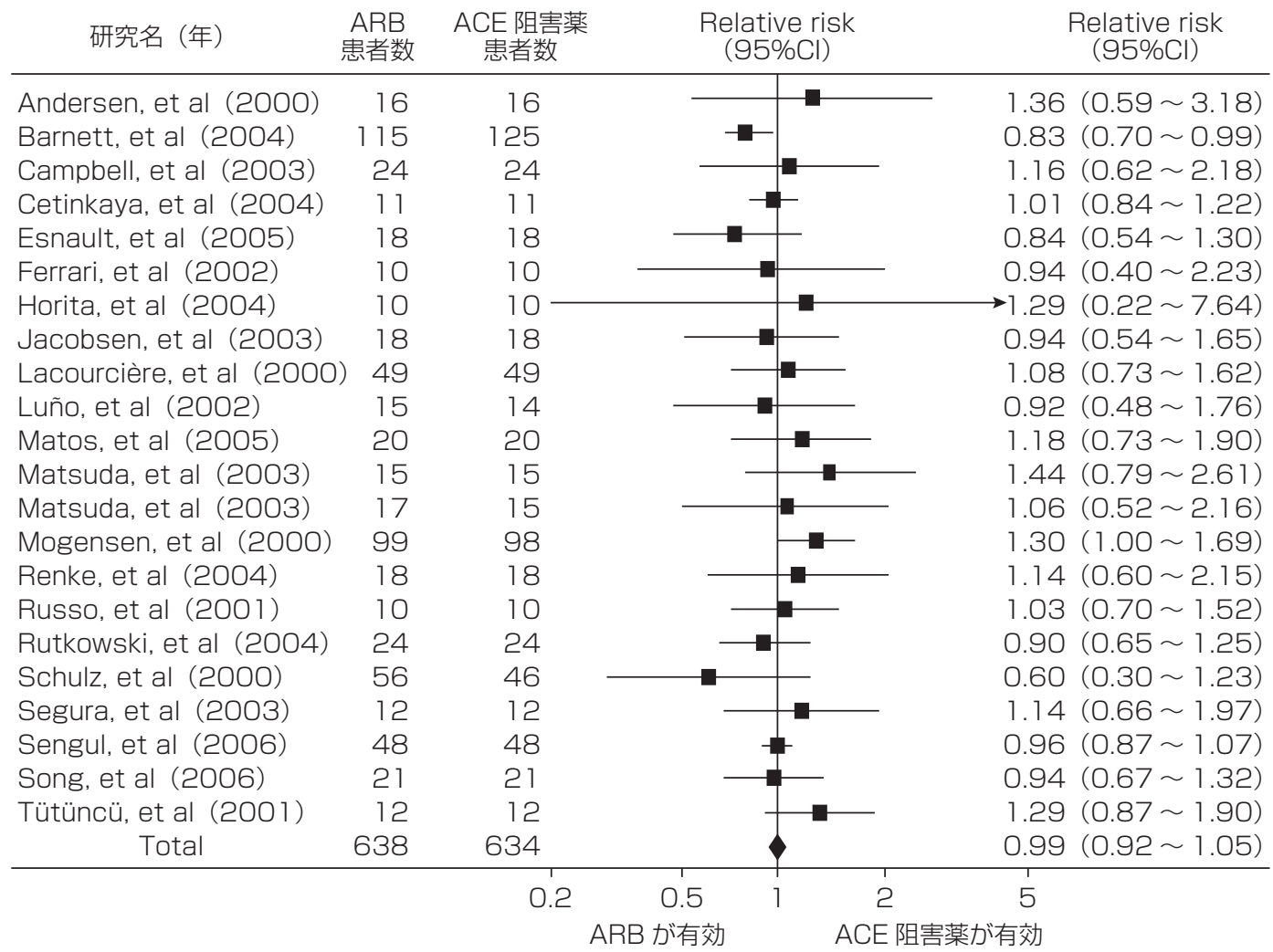

図 6. アンジオテンシン受容体拮抗薬（ARB）とACE阻害薬のタンパク尿低下作用は同等

(文献 8 より引用改変)

阻害薬の単剂とその併用の 3 群間で腎機能保護 効果に差がないばかりでなく，かえって，高カ リウム血症などの副作用が増加することから， その併用療法時には, 慎重な経過観察が必要で あることを報告している9 .

\section{RA系阻害薬とCKD患者におけるCVD}

Balamuthusamyらは, 25 の大規模臨床研究 (対象 $=45,758$ 人) からメ夕解析を行い, RA系阻 害薬の使用によって，心血管病，心筋梗塞，お よび心不全の発症を抑制できたこと,さらに糖 尿病性腎症の患者では, RA系阻害薬以外の薬剤 に比べて心不全を，また，非糖尿病性腎症患者 では，心血管病の発症を予防したことを報告し
ている ${ }^{10)}$.この報告から, RA系抑制薬が, $\mathrm{CKD}$ 患者においてCKDの進行ばかりではなく, CVD の発症を抑制することが示された.

\section{CKD患者のRA系抑制薬の併用薬は, 利 尿薬かCa拮抗薬か}

CKD患者に対する降圧薬として，これまで述 べてきたようにRA系阻害薬を使用することに異 論はないと思われる. しかし, 多くのCKD患者 では単剤で降圧目標に達することは難しく，併 用療法が必要である. JSH2009 では, RA系阻害 薬の併用薬として, 利尿薬もしくはCa拮抗薬の 併用を推奨している。 それでは，両薬郕でどち らの併用が臟器保護に有効なのだろうか.この 


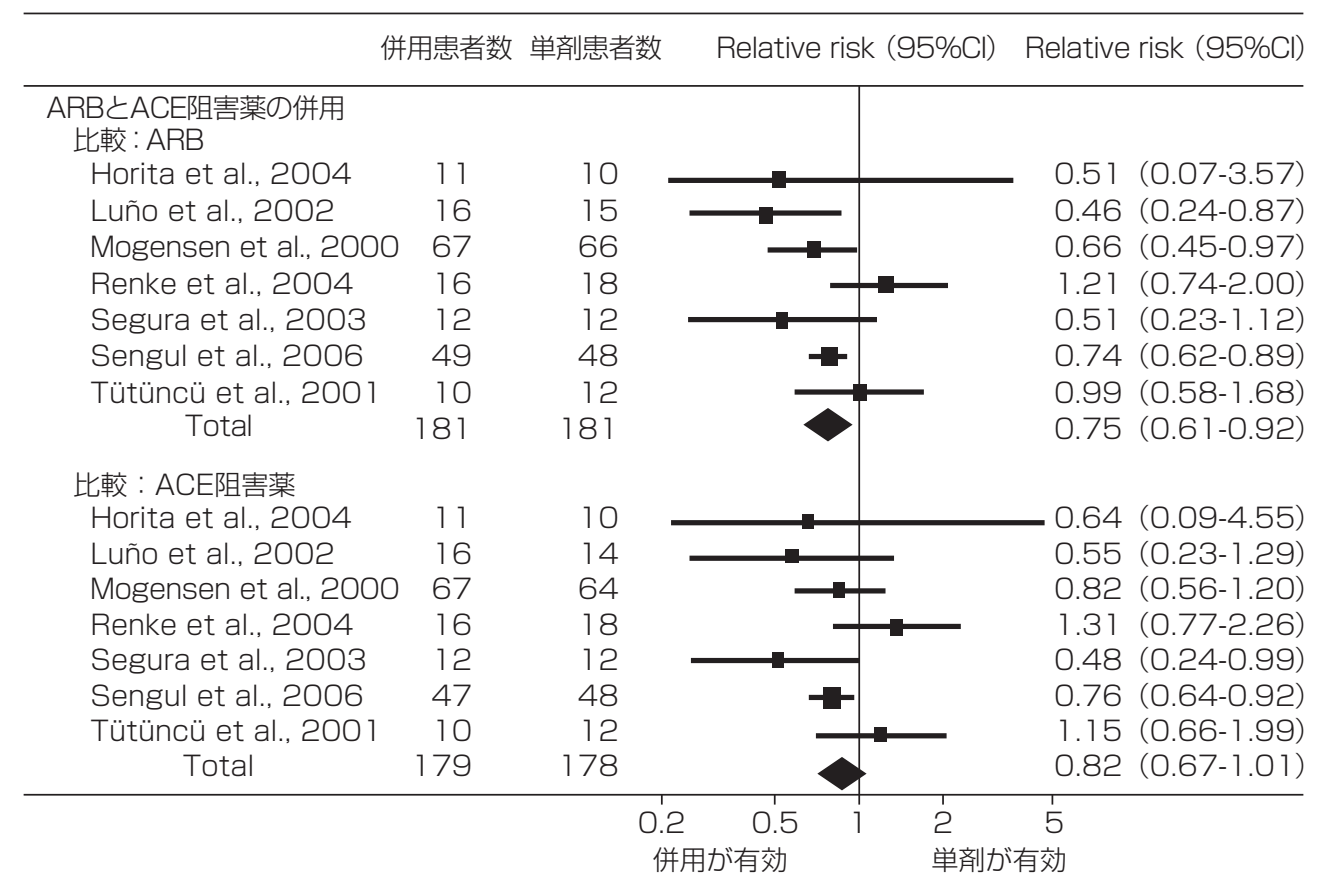

図 7. タンパク尿に対するアンジオテンシン受容体拮抗薬とACE阻害薬の併用効果

(文献 8 より引用改変)

答えが最近の臨床試験で明らかになりつつある. 2008 年にACE阻害薬 (ベナゼプリル) とサイア ザイド系利尿薬（ヒドロクロロチアジド）の併 用とACE阻害薬（ベナゼプリル）とCa拮抗薬 (アムロジピン)の併用を比較した試験が二つ報 告されている. ACCOMPLISH (Avoiding Cardiovascular Events through Combination Therapy in Patients with Systolic Hypertension)試験 では11)心血管疾患, 腎疾患, 標的蔵器障害を有す る高リスク高血圧患者を対象として, 上記 2 群 間で心血管病の発症（一次エンドポイント：心 血管死, 心筋梗塞, 脳卒中, 狭心症による入院, 心停止からの蘇生, 冠動脈の再建) 比較した. その結果, ACE阻害薬 + Ca拮抗薬群で有意に一 次エンドポントの発症を抑制した. 個々の因子 で差があったのは致死的および非致死的心筋梗 塞の発症および冠動脈の再建であった。このこ とから高リスク, 特に冠動脈疾患を有する高血
圧患者ではRAS阻害薬+Ca拮抗薬がRAS阻害 薬＋利尿薬よりも有効であることが示された. その後腎疾患に関するサブ解析が報告され, CKD の進行（クレアチニンの倍化，末期腎不全への 移行）に関しても，Ca拮抗薬の併用がより有効 であることが示された (図 8) ${ }^{12}$ 。ただし, 対象 を糖尿病性腎症に限って解析すると, CKDの進 行に差がなく, アルブミン尿を呈するCKD患者 では, ACE阻害薬 +Ca拮抗薬群と比較して, ACE 阻害薬 + 利尿薬群で有意にアルブミン尿を低下 させた. GUARD (Gauging Albuminuria Reduction with Lotrel in Diabetic Patients with Hypertension) ${ }^{13)}$ では,アルブミン尿を認める 2 型糖尿 病を合併した高血圧患者を対象として, 上記 2 剂間でアルブミン排泄量の低下作用に差がある かを検討した。 その結果, RAS阻害薬＋利尿薬 がRAS阻害薬 +Ca拮抗薬よりも有意に尿中アル ブミン排泄量を低下させた（図 9)。この二つの 


\section{トピックス}

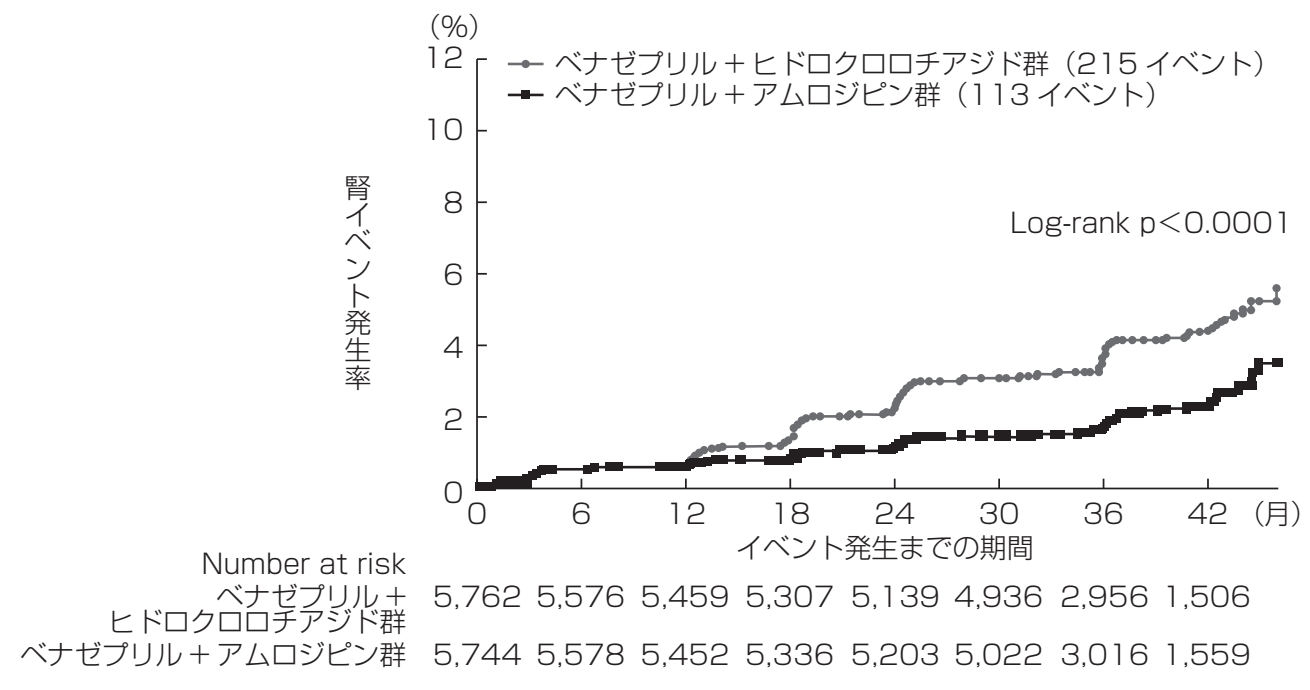

図 8. ハイリスク高血圧患者においてACE阻害薬の併用薬として利尿薬よりもCa拮抗薬が慢性 腎臟病の進展を抑制した

(文献 12 より引用改変)

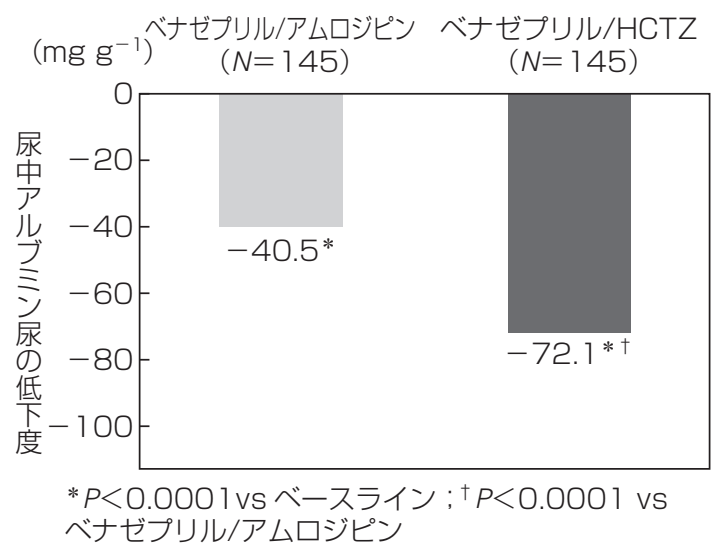

図 9. ACE阻害薬の併用薬によるアルブミン尿 低下作用の違い

(文献 13 より引用改変)

結果から結論づけることは困難ではあるが, CKD を有する高血圧患者, 特に糖尿性腎症患者では, RAS阻害薬 +利尿薬, 冠動脈疾患を有する高血 圧血圧はRAS阻害薬 +Ca拮抗薬が有効であるこ とが示唆される。したがって当然のことではあ るが, 降圧薬の選択には, 患者個々の病態に応 じて，第一選択薬および併用薬を吟味すること
が極めて重要であることがわかった.

おわりに

多くの臨床研究によって, CKDを有する高血 圧患者の治療法に関しては, 確立された部分も 多い.しかし，AppelらはCKD患者（GFR 20〜 $\left.65 \mathrm{ml} / \mathrm{min} / 1.73 \mathrm{~m}^{2}\right)$ にRA系阻害薬を使用して, 血圧をコントロールした（平均 $133 / 78 \mathrm{mmHg}$ ) 場合でも, 7 年間の経過観察で, 53.9\% の患者が, クレアチニンの倍増, 末期腎不全もしくは死亡 に至ったことを報告している ${ }^{14)}$.これらのことか ら, より早期からのRA系阻害薬を使用, 十分な 血圧コントロール, RA系阻害薬使用後の慎重な 腎機能管理が, 透析導入者を減少させ, 血管系 のイベントの抑制につながるものと考えられる.

著者のCOI (conflicts of interest) 開示: 本論文発表内容に 関連して特に申告なし 


\section{文献}

1) Klag MJ, et al: Blood pressure and end-stage renal disease in men. N Engl J Med 334 : 13-18, 1996.

2) Bakris GL, et al: Preserving renal function in adults with hypertension and diabetes: A consensus approach. Am J Kidney Dis 36 : 646-661, 2000.

3）日本高血圧学会 : 高血圧治療ガイドライン 2009 年版. 日 本高血圧学会高血圧治療ガイドライン作成委員会編. ラ イフサイエンス出版, 東京, 2009, 53-58.

4) Ogihara $T$, et al : Effect of candesartan compared with amlodipine in hypertensive patients with high cardiovascular risks : CASE-J trial. Hypertension 51 : 393-398, 2008.

5) Shlipak MG, et al : Cystatin $C$ and the risk of death and cardiovascular events among elderly persons. N Engl J Med 352 : 2049-2060, 2005.

6) Shlipak MG, et al:Cystatin $C$ and prognosis for cardiovascular and kidney outcomes in elderly persons without chronic kidney disease. Ann Intern Med 145 : 237-246, 2006.

7) Okura $\mathrm{T}$, et al: Association between cystatin $\mathrm{C}$ and inflammation in patients with essential hypertension. Clin Exp Nephrol 14: 584-588, 2010.

8) Kunz R, et al: Meta-analysis : Effedt of monotherapy and combination therapy with inhibitors of the renin- angiotensin system on proteinuria in renal disease. Ann Intern Med 148: 30-48, 2008.

9) Mann JF, et al: Renal outcomes with telmisartan, ramipril, or both, in people at high vascular risk (the ONTARGET study) : a multicentre, randomised, double-blind, controlled trial. Lancet $16: 547-553,2008$.

10) Balamuthusamy $\mathrm{S}$, et al:Renin angiotensin system blockade and cardiovascular outcomes in patients with chronic kidney disease and proteinuria : A meta-analysis. Am Heart J 155 : 791-805, 2008.

11) Jamerson $\mathrm{K}$, et al : Benazepril plus amlodipine or hydrochlorothiazide for hypertension in high-risk patients. $\mathrm{N}$ Engl J Med 359 : 2417-2428, 2008.

12) Bakris J, et al: Renal outcomes with different fixed-dose combination therapies in patients with hypertension at high risk for cardiovascular events (ACCOMPLISH) : a prespecified secondary analysis of a randomised controlled trial. Lancet 375 : 1173-1181, 2010.

13) Bakris GL, et al:Effects of different ACE inhibitor combinations on albuminuria : results of the GUARD study. Kidney Int 73 : 1303-1309, 2008.

14) Appel LJ, et al: Long-term effects of renin-angiotensin system-blocking therapy and a low blood pressure goal on progression of hypertensive chronic kidney disease in African Americans. Arch Intern Med 168: 832-839, 2008. 